\title{
The Energy of Gravitational Differentiation of The Earth's mantle (*)
}

\author{
E. N. I,YustikH \\ Ricevuto il 7 dicembre 1960
}

\section{1. - Introduction.}

In general, the Earth's crust consists of sialic rocks, (i.e. acidic and basic igneous and metamorphic rocks). It is suggested by many authors (Kropotkin 1953, Belousov 1954, Wilson 1957) that the crust grows gradually on account of permanent income of sial from the Earth's mantle, which consists of simatic or ultrabasic rocks. (Sial is generated due to the differentiation of the mantle: it is lifted up by buoyancy force and emerges in geosynclines). The hypothesis may be proposed that the floating up sial provides with energy all the tectonic processes. Thus the question arises whether the output of energy can be sufficient.

We may compute all the values to within an order only, since the necessary amount of energy is hardly known even to such exactness.

\section{2. - ENERGy Which CAN BE RELEASED.}

We may assume a flat Earth for our computations. The volume of the crust is $10^{25} \mathrm{~cm}^{3}$ today (Poldervaart 1955). The beginning of the forming of the crust may be $3.5 \times 10^{8}$ years ago, as the radioactive ages of rocks have shown. This gives the mean output of emerging sial $3 \times 10^{15} \mathrm{~cm}^{3} /$ year. It is believed that differentiation goes in the upper $700 \mathrm{~km}$ of the mantle only. Accepting this supposition we assume the mean depth, sial emerges from, to be as great as $350 \mathrm{~km}$, i.e. $3.5 \times 10^{7} \mathrm{~cm}$.

(*) Paper read at the Ilelsinky Assembly of the I.U.G.G. 1960. 
The density difference between sima and sial is $0.5 \mathrm{~g} / \mathrm{cm}^{3}$, or so. Gravity in the mantle is 1000 gals to within $2-3$ per cent. Taking these values we have.

$$
e=D g H v=5 \times 10^{25} \mathrm{erg} / \text { year },
$$

where: $e=$ mean output of energy,

$D$ - density difierence,

$y=$ gravity,

$H=$ mean depth sial emerges from

$v=$ mean output of sial

The part of the mantle undergoing differentiation loses light components and so grows heavier. At last it may plunge down and sink to the bottom of the mantle, provided the whole mantle is chemically homogeneous. Fresh matter will take its place, and differentiation may be resumed. For such "chemical convenction" we have to substitute $2.5 \times 10^{8} \mathrm{~cm}$ for $H$. So we get energy output $e-4 \times 10^{26} \mathrm{erg} / \mathrm{year}$, i. e. one order greater than from the differentiation of the upper part of the mantle.

Not all the energy released by the differentiation may be useful for tectonic movements. An allowance must be male for the efficiency of the transmission mechanism. The transmission may be very effective if sial ascends as a continuous sheet along a planetary rupture (we suppose every geosyncline is generated by a great "planetary" inclined rupture cutting the upper part of the mantle). On the contrary, if many isolated balls of sial emerge up through the mantle, the efficiency may be much less. We estimate presumable the efficiency $\beta$ in the range

$$
1>\beta>0.01
$$

then the possible contribution of energy to tectonics $T$ - $\beta$ e have limits

$$
10^{27}>T^{\prime}>10^{23} \mathrm{erg} / \text { year }
$$

\section{3. - NECESSARY AMOUNT OF ENERGy.}

The only way to estimate the amount of energy necessary for tectonic processes is to start from the average annual energy of all the seismic waves on the Earth, since in is the only geotectonic energy mea- 
surable. During 1896-1955 the mean power of seismic waves was $8.4 \times 10^{24} \mathrm{erg} / \mathrm{year}$, as it follows from the data of B. Gutenberg (1956). It is doubtful whether this figure may be representative for the whole period $3.5 \times 10^{9}$ years. To be cautions we estimate the seismic energy $z$ in the range

$$
10^{27}>z>10^{23} \mathrm{erg} / \mathrm{yerm}
$$

Only a part of energy released in foci turns into wave energy; the another part is immediately converted into heat. Taking this fact into considerations we assume for the whole ontput of energy in foci $Z$ the limits

$$
10^{20}>Z>10^{23} \mathrm{erg} / \mathrm{year}
$$

The power of all tectonic processes $T$ may be 10 to 1000 times as great as the power of seismic activity $Z$, so

$$
10^{31}>T>10^{24} \mathrm{erg} / \mathrm{year}
$$

\section{4. - Conclusion.}

As you have seen above, the tectonic power needed and the tectonic power available may coincide in the range

$$
10^{27}>T>10^{24} \mathrm{erg} / \mathrm{year}
$$

Thus the mechanism of differentiation can provide geotectonics with energy if the efficiency of this mechanism is high enough, and the required amount of energy is not much greater than the present energy of seismic waves.

\section{$S U M M A R Y$}

The Earth's crust has been forming owing to the differentiation of the mantle, "sial" being lifted by the forces due to gravity. As a result, the mean energy supply for tectonics might be as great as $10^{-3}-10^{27}$ erg/year. We estimate the energy of all tectonic processes at $10^{24}-10^{31}$ erg/year. So it may be suggested that the mechanism of differentiation provide geotectonics with energy. 


\section{RIASSUNTO}

La crosta terrestre si e andata formando a causa della differenziazione del mantello, dato che il "sial " viene sollevato dalle forze dovute alla gravita.

Di conseguenza il contributo medio di energia per la tettonica potrebbe raggiungere $i 10^{23}-10^{27}$ erg/anno. Noi calcoliamo l'energia di tutti $i$ processi tettonici a $10^{24}-10^{31}$ erg/anno. Si può cosi ritenere che il meccanismo della differenziazione fornisca l'energia alla geotettonica.

\section{REFERENCE}

Belousov V. V., (Белоусов В. В.) Основные вопросы геотектоники. "Госгеолтехиздат ", Москва (1954).

Gutenberg B., Tr. $A G U, 37$, n. 5, (1956).

Кropotкin P. N., (Кропоткии П. Н.) Известия $A H$ CCCP, серия геологич., 1 (1953).

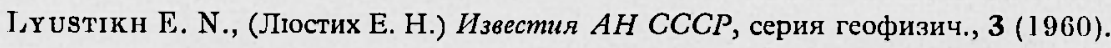
Poldervatit A., Geol. Soc. Am., Spec. Paper 62, (1955).

Wilson J. Tuzo, Nature, 179, No. 4553, (1957). 